\title{
First attempts for predicting future Salinization in coastal irrigated areas
}

\author{
A. RHIDOUANI ${ }^{1}$, I. IDRISSI ALAMI ${ }^{2 *}$ and M. ADDOU ${ }^{2}$ \\ ${ }^{1}$ Regional Laboratory of the National Office of Drinkable Water, \\ ${ }^{2}$ Laboratory for Optoelectronics and Physico-Chemistry of Materials, Kenitra, Morocco \\ URAC- 14 Ibn Tofail University, Faculty of Science, Kenitra, Morocco. \\ *Corresponding author; E-mail: idrissialami_ibtissam@yahoo.fr
}

\begin{abstract}
Salinity contamination of irrigation ground water is a serious worldwide problem. The Mnasra zone, which has an agricultural land area that represents $70 \%$ of the total area and its agricultural production reaches $12 \%$ of the national production, is threatened by a Salinization of underground waters. The ground water available in this region allows the supply of a population of 145000 inhabitants. We have developed a simple mechanistic simulation model for predicting future Salinization in this ground water. The method adopted to predict the variation of salinity pollution in ground water is the same as the population based on an increase (or decrease) geometry (geometric series). This work allows preparing for and coping with the environmental pollution that threatens not only humans, but also the fauna and flora of this region. According to this study, we predict an area of 8730 hectares where water will be polluted by the salinity in 2021 . These results will have a negative impact at medium and long terms on the agricultural production of this region.
\end{abstract}

(C) 2011 International Formulae Group. All rights reserved.

Keywords: Salinization, predicting, irrigated areas, groundwater, Region of Mnasra.

\section{INTRODUCTION}

The Salinization of ground waters has attracted considerable attention. International Studies have been carried out in the past by (Leclech et al., 1995; Laftouhi, 2003; Saadi et al., 2003). This problem is mainly due to the over-use of fertilizers and pesticides. The phenomenon of sea water invasion that can spread over kilometers inside lands is a serious risk for coastal zones that are dependent on ground waters for their supply in fresh water. Under certain conditions, salted water spread inside lands and contaminate ground waters from the water table that is located close to the sea. Thus, the invasion of fresh waters by salted waters will cause a degradation of soils and a Salinization due to irrigation trough these waters. The Gharb region, situated at the north-west of Morocco, which has a sandy soil, is confronted to nitrogen pollution. Studies carried out in this region (Ibnoussina et al., 2006; Idrissi Alami et al., 2007) have confirmed an alteration of the physical and chemical quality due to agricultural activities. Thanks to assets due to water quality (plenty of ground water resources) and to soils (soils have less than $6 \%$ of clay and more than $82 \%$ of sand (Idrissi Alami, 2009), the coastal zone of Mnasra has witnessed an increase of the area of irrigated zones from 5,766 ha in 1998 to 39,686 ha in 2005 . Today, the irrigated 
zone is facing an important diversification of vegetable crops (pepper, potato, tomato, aubergine, watermelon, cabbage, carrot, turnip...) and exotic crops (banana, strawberry, avocado...). This crop diversity is unfortunately associated with an over-use of fertilizers and pesticides that cause a nitric pollution of Mnasra's water table (Ibnoussina et al., 2006).

It is important to notice that the water table of Mnasra is also confronted with other kinds of pollution due to sea water intrusion and to crop intensification, especially the sodization of ground waters.

According to Peterson (1999), the main problem with a big quantity of sodium and salinity is its effect on soil permeability and on water infiltration. Sodium also directly contributes to water's total salinity and can be toxic for sensitive crops such as carrots, beans, strawberries, raspberries, onions etc. (Ayadi et al., 2002; Maalej et al., 2002). The sodization of ground waters of irrigated areas has generated a particular attention at the international scale and in different region of the world like in China (Vincent et al., 2003), in Pakistan (Condom et al., 1999), in Niger and in Mali (Bertrand et al., 1992). Several numerical models of water transport and agrochemicals have been developed to predict the fate of solutes in agricultural soils (Benbi et al., 1991).

In this way, this work has the objective of, firstly, evaluating the Salinization of the water of Mnasra's water table used for irrigation, secondly, studying the spatial and temporal evolution of this water table, and finally, predicting the future Salinization in ground water located at Mnasra zone.

\section{MATERIALS AND METHODS \\ Data and sample collection}

A study was performed in the water region of Mnasra, on water quality. Mnasra is an agricultural land. Water quality survey was performed and water samples from various wells were collected and analysed in laboratory. A total of 170 samples of ground waters were collected during two periods of companions: 1993 and 2007.

\section{Well selection}

The choice of these wells was essentially based on two criteria: the crop intensification and the depth of the water table (Figure 1).

\section{Measurement methodology}

Also, the method chosen to predict the variation in groundwater sodisation of the water table of Mnasra is the geometric series. With this mathematical model, we calculated future concentrations of salinity in 2021: We have assumed that: $\mathrm{q}=$ constante. We knew the Salinity measured at 170 wells during periods of companions in 1993 and 2007. With this model, we can calculate the constant $\mathrm{q}$ at the end of 14 years, as an example, from the following equation:

\section{(1) $U_{N}=q^{n} \times \boldsymbol{U}_{0}$}

Where: $\mathrm{U}_{\mathrm{N}}=$ Salinity in 2007; $\mathrm{n}=$ Number of years between the two concentrations $(n=$ $\mathrm{N}-0=14$ )

$\mathrm{U}_{0}=$ Salinity in 1993

We calculate $q=$ ?

From equation (1) :

[Salinity in 2007] $=\mathrm{q}^{14} \times[$ Salinity in 1993] And then :

$\mathrm{q}^{14}=$ [ Salinity in 2007] / [ Salinity in 1993] And then :

(2) $q=10^{1 / 14 \times \log ([\text { Salinity in 2007] } / \text { [ Salinity in 1993] ) }}$ With this mathematical model, we calculated future Salinity in 2021 for 170 samples:

[Salinity in 2021] $=(2) \times$ [Salinity in 2007]

\section{Measurement of the salinity}

The samples of this study were measured on the field by electrometric method, by means of a conductimeter. The conductivity was measured in the site of collection by means of a portable conductimeter. The recorded values were then standardized, thanks to the correlative coefficient at $20^{\circ} \mathrm{C}$ (Rodier, 1984). 


\section{RESULTS}

\section{Statistical analysis}

The main results show that the overall average Salinity calculated in 2021 is 1.20 . We compared the Salinity calculated in 2021 with the results measured in 1993 and 2007. Table 1 shows the average levels of Salinity, levels Max, Min, and deviation types calculated for the 170 wells in 1993, 2007 and 2021. We obtained the results presented in Table 1 and Figure 2.

The comparison of the overall average of calculated Salinity allows observing clearly that this average will continue to increase as well during the companion 2021. And, in order to see the significance of this increase, we called for a study of variance. The results of the analysis of variance of the 170 wells and each zone A and B are displayed in Table 2.

The statistical analysis confirms that the zone at the North of the line $Y=430000$ $\mathrm{m}\left(38^{\circ} 30^{\prime}\right)$ is the zone which is the most affected by Salinization. Indeed, it corresponds to the largest area of the sandy zone, where dunes and interior plateaus have a low relief, from 5 to $20 \mathrm{~m}$ high. As a consequence, the water table is very close to the surface ( 3 to $10 \mathrm{~m}$ ); this explains the current intensive exploitation and the over-use of fertilizers that are often composed of salts. Thus, the Southern zone, has known a significant increase of Salinization. This is mainly due to sea water intrusion in this zone.

\section{Spatial analysis}

According to our analytical results, we have used the Geographical Information System (GIS) Arcvie and its spatial extension analyst, to create maps of the calculated Salinity in 2021 (Figure 3). We compared the latter with the thematic maps of Salinity measured during periods of companions: 1993 and 2007 level of 170 wells (Figure 4).

The rough analysis of the above cards, confirmed the sodisation more pronounced in the North of Mnasra. In order to predict which area will be occupied by each class of the
Salinity, and in order to better illustrate the spatial results presented in Figures 3 and 4, we have plotted them in a bar chart represented in the Figure 5.

We can see clearly that the areas occupied by the class $\mathrm{C} 1(0-1 \mathrm{mS} / \mathrm{cm})$ continue to decrease during the companion 2021. Moreover, the areas occupied by the classes $\mathrm{C} 2$ (1-2 mS/cm), C3 $(2-2,7 \mathrm{mS} / \mathrm{cm})$ and $\mathrm{C} 4(>2,7$ $\mathrm{mS} / \mathrm{cm}$ ) will continue to increase during the same periods companion. And to better express this variation of sodium, we have expressed the latter in percentages.

We have summarized the results in Table 3 and presented these data in a bar chart in Figure 6.

The area covered by the water table having a Salinity inferior to $2,7(\mathrm{mS} / \mathrm{cm})$

The area covered by the water table that has a good quality on the salinity point of view is localized along the right bank of the Oued Sebou and in the coastal merjas (Sidi Mohammed Ben Mansour Merja and Merja daoura). The area covered by the water table having a Salinity inferior to $2,7(\mathrm{mS} / \mathrm{cm})$ has lost in importance i.e. loss of $4229 \mathrm{Ha}$ between 1993 and 2021.

Therefore, this frequency is around $92 \%$, $85 \%$, and $81 \%$, respectively, during the measurement periods in 1993, 2007 and 2021.

The area covered by the water table having a Salinity superior to $2,7(\mathrm{mS} / \mathrm{cm})$

The area covered by the water table having a Salinity superior to $2,7(\mathrm{mS} / \mathrm{cm})$ has spread in importance, i.e. loss of 4501 between 1993 and 2021. Therefore, this frequency is around $8 \%, 15 \%$, and $19 \%$, respectively, during the measurement periods in 1993, 2007 and 2021.

The comparison of the spatial results allows us to confirm a decrease of $11 \%$ in the area in which the table water has a Salinity inferior to 2,7 $(\mathrm{mS} / \mathrm{cm})$ between 1993 and 2021. And consequently, we predict an area of $8730 \mathrm{Ha}$ where the water will be polluted by the Salinity in 2021. 
Table 1: Average levels of Salinity levels Max, Min, and deviation types calculated for the 170 wells in 1993, 2007 and 2021.

\begin{tabular}{lccc}
\hline Parameter & \multicolumn{3}{c}{ Salinity } \\
\hline Year & $\mathbf{1 9 9 3}$ & $\mathbf{2 0 0 7}$ & $\mathbf{2 0 2 1}$ \\
Max Value & 4,14 & 7,79 & 9,34 \\
Min Value & 0,3 & 3,31 & 0,29 \\
Standard deviation & 0,52 & 0,53 & 1,03 \\
Mean & 0,85 & 1,10 & 1,20 \\
WHO standard & 2,7 & 2,7 & 2,7 \\
\hline
\end{tabular}

Table 2: Results of the analysis of variance of the Salinity for 170 wells and each zone A and B between 1993, 2007 and 2021.

\begin{tabular}{lccc}
\hline $\begin{array}{l}\text { Statistical analysis of } \\
\text { wells from }\end{array}$ & $\begin{array}{c}\text { Between 1993 } \\
\text { and 2021 }\end{array}$ & $\begin{array}{c}\text { Between 1993 } \\
\text { and 2007 }\end{array}$ & $\begin{array}{c}\text { Between 2007 } \\
\text { and 2021 }\end{array}$ \\
\hline Globale (170 puits) & HS & HS & S \\
Zone A & HS & HS & S \\
Zone B & S & S & S \\
\hline
\end{tabular}

S : Significant difference; HS : Highly significant difference

Table 3: Percentage of area occupied by Salinity pollution of each class of wells on the total land mapped in 1993, 2007 and 2021.

\begin{tabular}{|c|c|c|c|c|}
\hline \multirow{3}{*}{ Year } & \multicolumn{4}{|c|}{ Area occupied by class of Salinity / total land mapped $* 100$} \\
\hline & Class 1 & \multirow{2}{*}{$\begin{array}{c}\text { Class } 2 \\
(1-2) \mathrm{mS} / \mathrm{cm}\end{array}$} & \multirow{2}{*}{$\begin{array}{c}\text { Class } 3 \\
(2-2,7) \mathrm{mS} / \mathrm{cm}\end{array}$} & Class 4 \\
\hline & $(0-1) \quad \mathrm{mS} / \mathrm{cm}$ & & & $>2,7 \mathrm{mS} / \mathrm{cm}$ \\
\hline 1993 & $65 \%$ & $19 \%$ & $8 \%$ & $8 \%$ \\
\hline 2007 & $49 \%$ & $22 \%$ & $14 \%$ & $15 \%$ \\
\hline 2021 & $43 \%$ & $23 \%$ & $15 \%$ & $19 \%$ \\
\hline
\end{tabular}

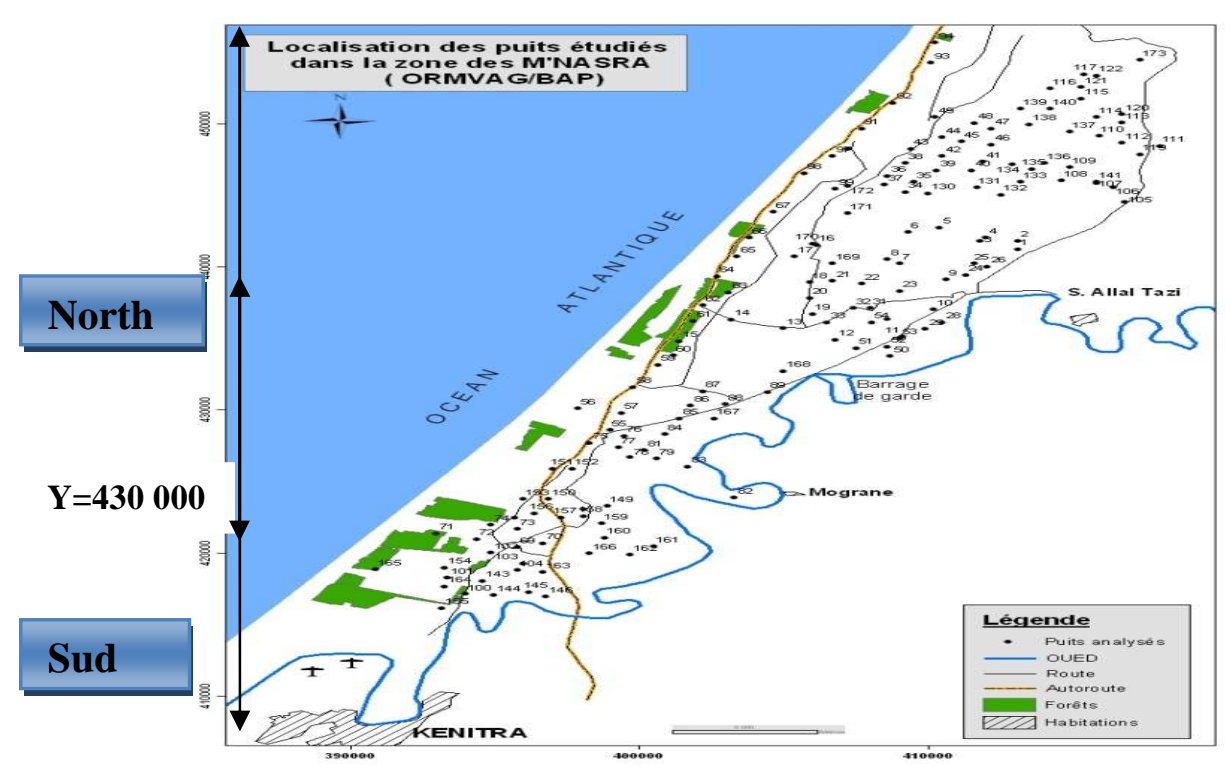

Figure 1: Localization of 170 wells studied in the zone of Mnasra. 


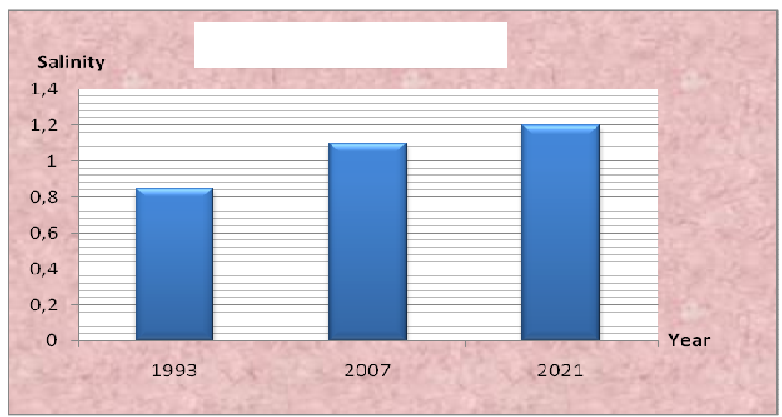

Figure 2: The average levels of Salinity of the waters coming from the 170 wells of Mnasra in 1993, 2007 and in 2021.

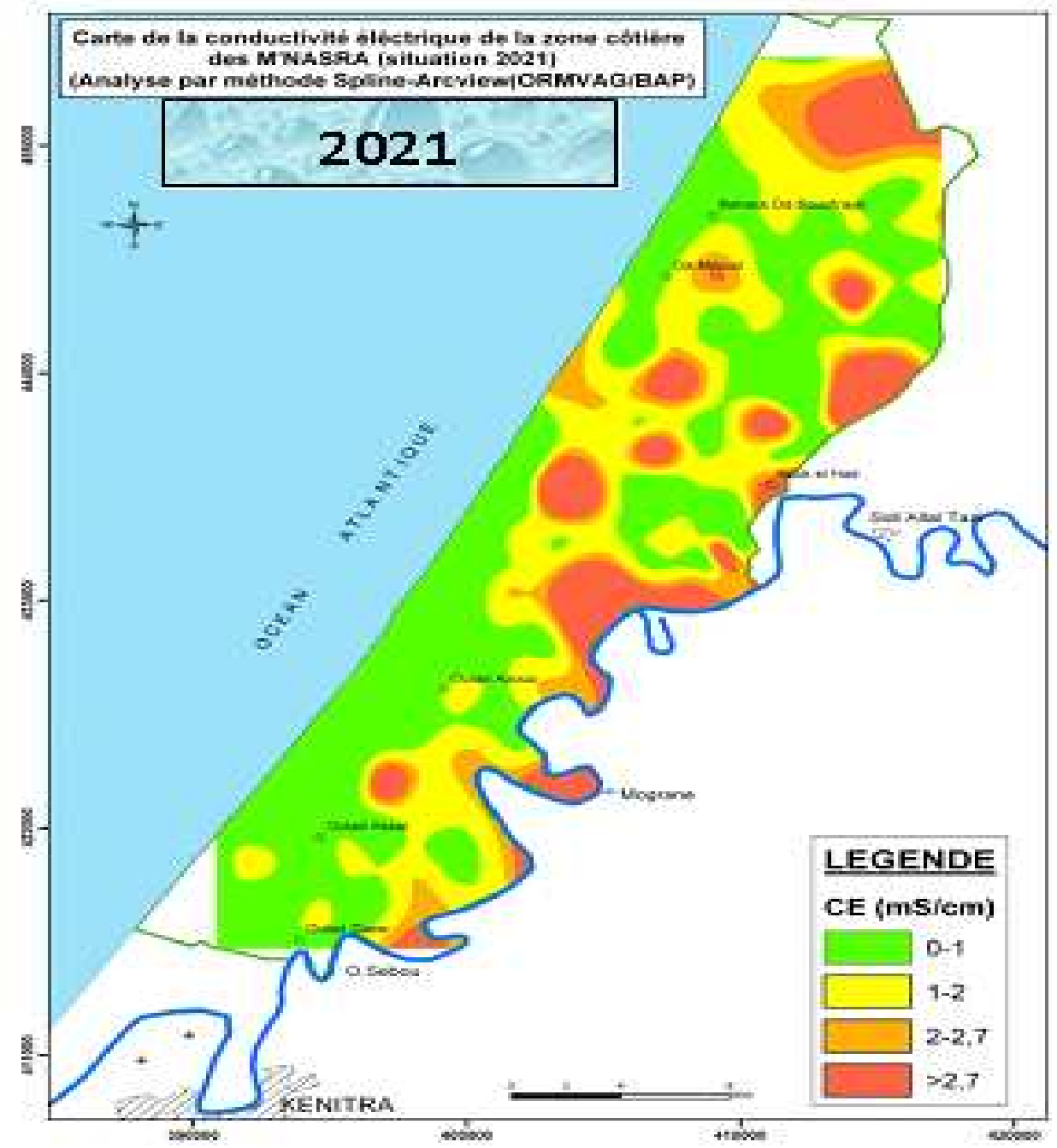

Figure 3: Maps of the Salinity in Mnasra zone (Morocco) in 2021. Analysis through Spline Arcview method. 

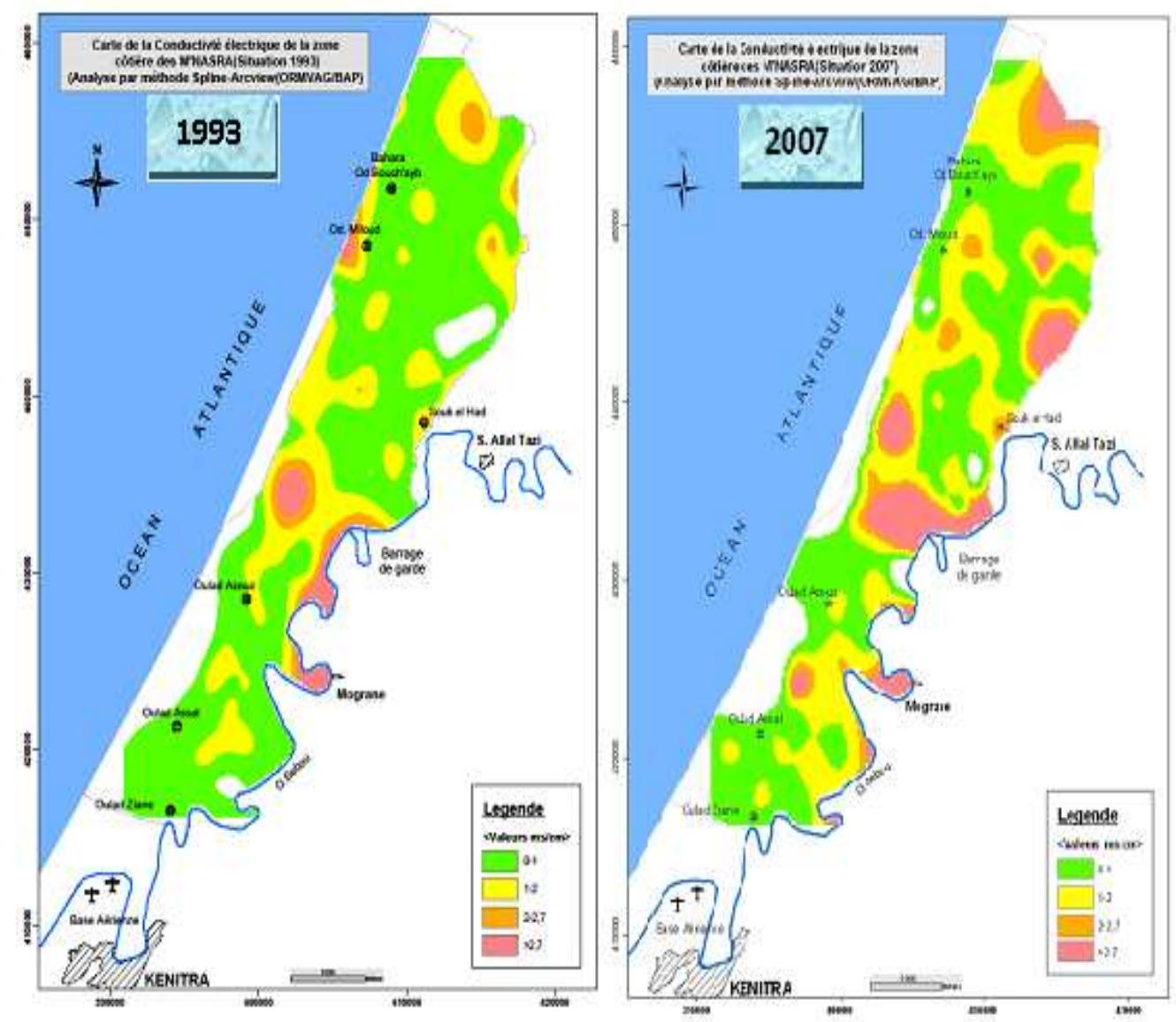

Figure 4: Maps of the Salinity in Mnasra zone (Morocco) in 1993 and 2007. Analysis through Spline Arcview method.
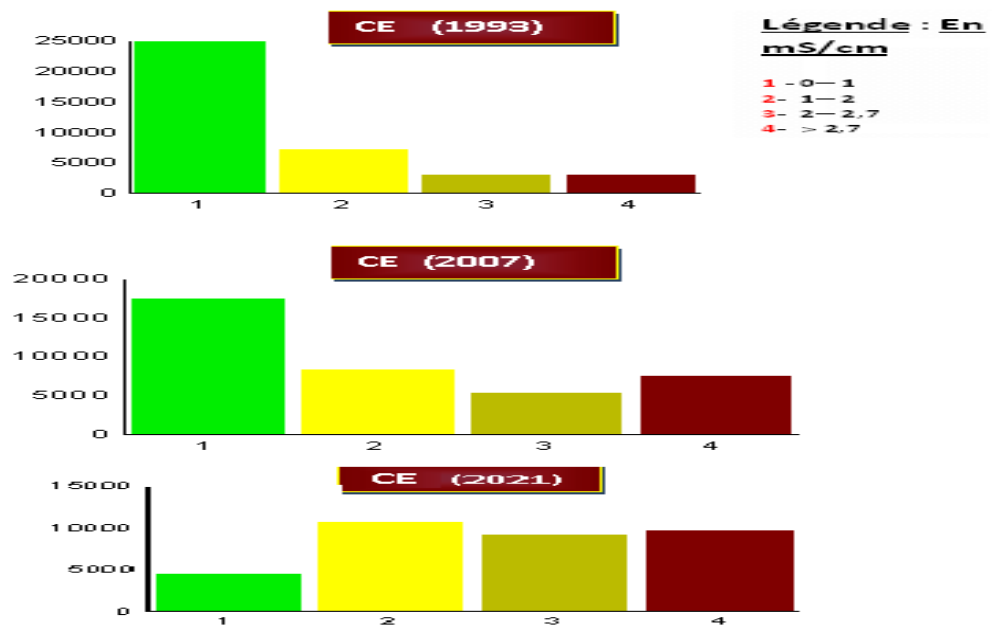

Figure 5: Spatial repartition of the four classes of the Salinity in 1993, 2007 and 2021. 


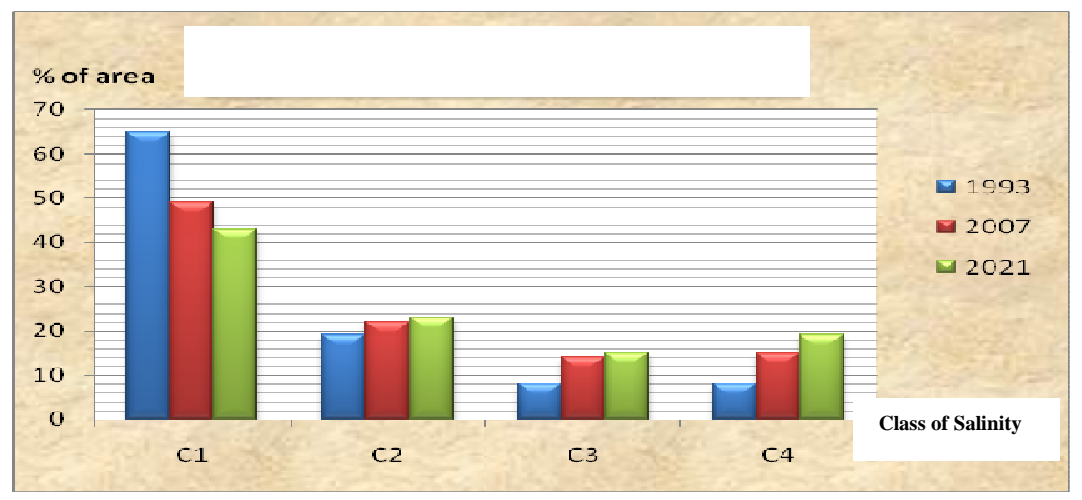

Figure 6: Variation of the percentage of the area covered by the water table having Salinity in function of time.

\section{DISCUSSION}

The obtained results confirm the variation of the Salinization of the water table at a local level and at the spatial level as well.

Indeed, the studied region belongs to these coastal zones where the only water resources are from underground origin, flow in a heterogeneous aquifer, which is mainly supplied by wells waters (Meybeck, 1986). The hardness refers to the quantity of calcium and magnesium contained in water. These two elements come from the alteration of the mother-rock. The concentration of calcium is usually higher than the concentration of magnesium in ground waters. On the other hand, where we can find more contamination by sea water, the concentration of magnesium can be more important than the concentration of calcium. Generally, hard water is not desirable for domestic use, because it dramatically reduces the efficiency of soaps. Whereas in agriculture, hard water helps the soil to keep a good structure thanks to calcium bounds (Peterson, 1999). In Quebec, water rich in calcium and in magnesium usually has equivalent quantities of bicarbonate or carbonate that confers a higher alkalinity. This is a tricky issue! When alkalinity is high, calcium and magnesium are the two main elements which cause water inlay problems and which can progressively block the tap drip by hard calcium deposit. It sometimes happens that the water hardness is high but its alkalinity is not. This is the case when calcium and magnesium of water are under the form of sulfate and chlorides (Peterson, 1999). Finally, our results comply with several studies that have been published at the international scale to focus the attention on the risks caused by the increase of the salinity on plankton populations (EL Guilli, 2000; and Hernandez, 2000; Mezni et al., 2002).

\section{Conclusion}

This study concerns the first attempts for the prediction of future Salinity concentrations in ground water in 2021 of 170 wells spread over an area of $38,000 \mathrm{Ha}$, and on the other hand to study the spatial and temporal evolution of the Salinity by a statistical analysis following the campaign periods of 1993 and 2007. The analysis of the results has shown the evolution of the general average of the concentration in Salinity between the years 1993, 2007 and 2021 which is respectively $0.85,1.10$ and 1.20 , i.e. an increase of 0,35 . According to this study, we predict an area of 8730 hectares where the water will be polluted by the Salinity in 2021 . These results confirm that there is an overexploitation of the water table, a largescale use of nitrate fertilizers and pesticides.

\section{REFERENCES}

Ayadi H, Toumi N, Abid O, Medhioub K, Hammami M, Sime-Ngando T, Amblard C, et Sargos D. 2002. Etude qualitative et quantitatives phyto- et 
zooplanctoniques dans les bassins de la saline de SfaxTunisie. Sci. Eau, 15(1): 123-135.

Benbi DK, Prihar SS, Cheema HS. A model to predict changes in soil moisture, NO3 $\mathrm{N}$ content and $\mathrm{N}$ uptake by wheat.1991. Fertilizer Research., 28(1): 73-84.

Bertrand R, Keita B, N'Diaye MK.1992. Dégradation des sols des périmètres irrigués des grandes vallées sudsahariennes Cas de l'Office du Niger au Mali. Cahiers Agricultures, 2(5): 318329.

Condom N, Kuper M, Marlet S, VallesV, Kijne JW. 1999. Salinization, alkalinization and sodification in Punjab (Pakistan): characterization of the geochemical and physical processes of degradation. Land Degradation and Development, 10(2): 123-140.

EL Guilli M, Benyahia H, Jrifi A, Besri M. 2000. Effect of the irrigation water salinity on the trunk gummosis symptom severity for citrus affected with Phytophthora citrophthora. Fruits CODEN Fruias., 55(3):181-186.

Hernandez S, Deleu C, LArher F. 2000. Proline accumulation by leaf tissues of tomato plants in response to salinity. Elsevier Paris., 323(6): 551-557.

Ibnoussina M, Maslouhi A, Zeraouli M 2006. Effect of clay amendement on the dynamics of nitrogen $(\mathrm{N})$ through the profil of a sandy soil .Hydrologial Science and technology, 22(14): 107-118.

Idrissi Alami I, Rhidouani A, Zeraouli M, Haidar A, Echchelh A, Addou M. 2010.Spatial and temporal study of the physical and chemical quality of groundwater: Case of M.nasra (Morocco). Environmental Science, 5(1): 51-58.

Idrissi Alami I, Zeraouli M, Addou M, Moukhtari A, Soulaymani A, 2007. Évaluation de la pollution nitrique de la nappe phréatique de la zone côtière du Gharb (M'nasra) au Maroc entre 1993 et 2003. Afriq Sci., 3(3): 378-390.
Laftouhi N, Vancclooster M, JalalM, Witam O, Aboufirassi M, Bahir M, Persoons E. 2003. Groundwater nitrate pollution in the Essaouira Bassin (Morocco). C. R. Geoscience, 335: 307-317.

Leclech B. 1995. Environnement et Agriculture. Synthèse Agricole ; 290.

Maalej S, Mahjoubi A, Kammoun A, Bakhrouf-Fadhila A. 2002. Les Aeromonas mobiles : quelle evolution spatiale et temporelle dans un effluent urbain et en milieu marin côtier. Sci. Eau, 15(1): 273-287.

Meybeck M. 1986. Composition chimique des ruisseaux non pollués de France. Sci. Géol. Bull., 39: 3-77.

Mezni M, Albouchi A, Essia B, Mongi H. 2002. Effet de la salinité des eaux d'irrigation sur la nutrition minérale chez trois variétés de luzerne pérenne (Medicago sativa). Agronomie, 22: 283291.

OMS. 1979. Organisation mondiale de la santé. Sodium, chlorures et conductivité dans l'eau potable. Rapport d'un groupe de travail de l'OMS. EURO rapports et études 2, bureau régional pour l'Europe, Copenhague.

Peterson HG.1999.Water quality Fact Sheet: Irrigation and Salinity. Agriculture et Agroalimentaire: Canada; 4.

Rodier F. 1984. Decomposition of principal series for reductive $\mathrm{p}$-adic groups and the Langlands' classification. Operator algebras and group representations, II; 86-94.

Saadi Z, Maslouhi A. 2003. Modeling nitrogen dynamic in the unsaturated soils for evaluating the nitrate contamination of the M'nasra groundwater. $A d v$. Environ. Res., 7(4): 803-823.

Vincent B, Pereira LS, Cai LG, Musy A, Minhas PS.2003. Remote sensing for spatial analysys of irrigated areas. Water savings in the Yellow River Basin. Beijin China Agriculture Press ; 29-45. 